\title{
Kelainan Refraksi Mata pada AnaK
}

\author{
Bella A. Saiyang, ${ }^{1}$ Laya M. Rares, ${ }^{2}$ Wenny P. Supit ${ }^{2}$
}

\author{
${ }^{1}$ Program Studi Pendidikan Dokter Fakultas Kedokteran Universitas Sam Ratulangi, Manado, \\ Sulawesi Utara, Indonesia \\ ${ }^{2}$ Bagian Ilmu Kesehatan Mata Fakultas Kedokteran Universitas Sam Ratulangi, Manado, \\ Sulawesi Utara, Indonesia \\ Email: bellasaiyang@gmail.com
}

\begin{abstract}
Refractive errors (ametropia) is caused by abnormality of the axial length or abnormality of refractive power of the eye. In children, refractive errors could cause blindness dure to lack of family attention. This study was aimed to obtain the general view of refractive errors among children. This was a literature review study using data of Google Search, ClinicalKey, and Google Scholar. Data were selected based on inclusion and exclusion criteria. There were 10 literatures selected, consisting of 2 case control studies and 8 cross-sectional studies. The results showed that refractive errors in children -myopia, hypermetropia, and astigmatism- were increasing not only in Indonesia. Refractive errors in children were classified according to sex and age with different disorders. Each child was examined by using gold standar. In conclusion, refractive errors in children were myopia, hypermetropia, and astigmatism. There was no significant difference between male and female. In children, studies of various age groups ranging from elementary to high school. This disorder could also occur based on the children's activities, therefore, family attention was really needed.
\end{abstract}

Keywords: refractive errors, children

\begin{abstract}
Abstrak: Kelainan refraksi (ametropia) dapat diakibatkan adanya kelainan axial length atau daya refraksi mata. Pada anak, gangguan refraksi menjadi salah satu penyebab kebutaan terbesar tanpa adanya perhatian dari keluarga. Penelitian ini bertujuan untuk mendapatkan gambaran umum kelainan refraksi mata pada anak. Jenis penelitian ialah literature review. Pencarian data didapatkan dari Google Search, ClinicalKey dan Google Scholar. Seleksi data berdasarkan kriteria inklusi dan ekslusi, dan didapatkan 10 literatur yang terdiri dari 2 case control dan 8 studi potong lintang. Hasil penelitian mendapatkan bahwa kelainan refraksi pada anak berupa miopia, hipermetropia, dan astigmatisma yang meningkat bukan hanya di Indonesia. Kelainan refraksi pada anak digolongkan berdasarkan jenis kelamin dan usia dengan kelainan yang berbeda-beda. Setiap anak dilakukan pemeriksaan dengan menggunakan baku emas. Simpulan penelitian ini ialah kelainan refraksi pada anak dapat berupa miopia, hipermetropia, dan astigmatisma. Tidak terdapat perbedaan bermakna antara jenis kelamin laki-laki dan perempuan. Penelitian pada anak dilakukan pada berbagai golongan usia mulai dari sekolah dasar sampai sekolah menengah. Kelainan refraksi dapat pula terjadi berdasarkan aktivitas yang dilakukan anak sehingga perhatian dari keluarga sangat dibutuhka.
\end{abstract}

Kata kunci: kelainan refraksi, anak

\section{PENDAHULUAN}

Mata memiliki peran penting, terutama sebagai indera penglihatan. Selain pertimbangannya sebagai jendela jiwa, mata juga dapat berfungsi sebagai jendela identitas seseorang. ${ }^{1}$ Mata yang terlihat normal, tidak menutup kemungkinan terganggunya penglihatan yang jelas. ${ }^{2}$

Kelainan penglihatan/refraksi adalah 
suatu keadaan yang disebabkan oleh kelainan pada axial length ataupun kelainan daya refraksi media. ${ }^{3}$ Kelainan refraksi yang tidak terkoreksi menjadi salah satu penyebab tersering bagi gangguan pengelihatan. Jika seorang anak mengalami kelainan refraksi dan tidak dapat dikoreksi, maka akan muncul beberapa gangguan penglihatan yang dialami, seperti sulit konsentrasi atau melakukan aktivitas yang dapat memengaruhi pembelajaran anak. ${ }^{4}$

Kelainan refraksi juga menjadi salah satu penyebab utama gangguan penglihatan pada anak, terutama usia 5-15 tahun. ${ }^{5}$ Sekitar $90 \%$ anak biasanya mengalami kelainan refraksi, terlebih miopia yang meningkat secara tajam. ${ }^{6}$ Saat ini prevalensi kelainan refraksi pada anak meningkat tajam, salah satunya di bagian Asia Tenggara. ${ }^{7}$ Menurut Kementerian Kesehatan RI, kasus kelainan refraksi mencakup $70 \%$ dari seluruh penyebab kebutaan. ${ }^{8}$ Masalah penglihatan yang dapat diobati pada anak sering terjadi, dengan prevalensi 13\%-23\%. Masalah yang sering ditemukan pada anak usia 9 tahun termasuk kelainan refraksi; di Eropa Barat, $15 \%-20 \%$ anak mengalami kelainan refraksi, termasuk hiperopia yang menurun saat remaja, miopia yang meningkat, dan astigmatisme. Selain itu, terdapat variasi geografis yang bermakna, dan khususnya, tingkat miopia mewabah di Asia Timur dan Tenggara. $^{9}$

\section{METODE PENELITIAN}

Penelitian ini menggunakan metode literature review. Pencarian literatur dilakukan dengan menggunakan pencarian khusus artikel ilmiah seperti Clinical Key, Google Search, dan Google Scholar. Pencarian dilakukan dengan memasukan kata kunci berupa kelainan refraksi OR kelainan refraksi pada anak OR refractive errors OR refractive errors in children $\mathrm{OR}$ myopia pada anak OR hypermetropia pada anak OR astigmatisma pada anak dengan berbagai variasi dan terjemahan. Literatur yang diperoleh kemudian diskrining menggunakan kriteria inklusi dan eksklusi dengan cara membaca judul dan cuplikan abstrak artikel tersebut. Literatur penelitian yang meme- nuhi syarat dari skrining dibaca keseluruhannya untuk memastikan informasi yang dapat digunakan dalam menjawab rumusan masalah dan menyelaraskan tujuan penelitian.

Pada studi ini didapatkan literatur sebanyak 2.114 Google Scholar, 61.100 Google Search, dan 8144 Clinical Key yang sesuai dengan kata kunci tersebut. Dari hasil pencarian kemudian dilakukan skrining berdasarkan judul sesuai dengan tema literature review yang di dapat.

\section{HASIL PENELITIAN}

Tabel 1 memperlihatkan hasil kajian literature yang digunakan dalam penelitian ini yaitu 10 artikel yang memenuhi kriteria inklusi, terdiri dari 2 penelitian case control dan 8 penelitian potong lintang. Literatur yang dicantumkan membahas mengenai penelitian pada anak dari berbagai golongan usia serta kelainan refraksi yang dialami. Jumlah dan persentase yang didapatkan juga dicantumkan. Jumlah sampel yang diambil dari 10 literatur yang didapati berkisar puluhan sampai ribuan anak yang dimasukkan dalam penelitian.

Pada literatur pertama oleh Enira $^{3}$ sebanyak 80 responden diperiksa dengan menggunakan Snellen chart dan pinhole, dan didapatkan 34 responden dengan kelainan refraksi. Dari 80 responden, sebanyak 33 responden $(58,8 \%)$ perempuan dan 47 responden $(41,2 \%)$ laki-laki. Pada penelitian ini juga digunakan kategori berdasarkan usia anak, yaitu dari 80 responden sebanyak 46 responden $(57,5 \%)$ berusia $9-12$ tahun dan 34 responden $(42,5 \%)$ berusia 6-8 tahun. Selain itu kelainan refraksi pada usia 9-12 tahun lebih kecil $(26,1 \%)$ dibandingkan usia 6-8 tahun $(64,7 \%)$.

Pada literatur kedua oleh Mihartari et $\mathrm{al}^{4}$ terdapat sebanyak 30 pasien yang diperiksa melalui data sekunder dan hasil rekam medis pasien terdapat sebanyak 29 pasien mengalami kelainan refraksi terdiri dari 16 laki-laki $(53,3 \%)$ dan 14 perempuan $(46,7 \%)$. Terdapat juga dua kelompok usia yaitu 9-12 tahun $(63,3 \%)$ dan 6-8 tahun $(36,7 \%)$. Didapatkan juga jenis kelainan refraksi berupa miopia sebanyak 15 anak 
(25,0\%), hipermetropia sebanyak 6 anak $(10,0 \%)$, astigmatisma sebanyak 29 anak $(48,3 \%)$, miopia astigmat sebanyak 8 anak $(13,3 \%)$, astigmat mikstus 1 anak $(1,7 \%)$, dan emetropia 1 anak $(1,7 \%)$.

Pada literatur ketiga oleh Ratanna et al, ${ }^{10}$ sebanyak 163 penderita diperiksa melalui hasil rekam medis, dan didapatkan 66 anak laki-laki (40,49\%) dan 97 anak perempuan $(59,51 \%)$. Dengan berbagai golongan usia, mulai dari $<1$ tahun sebanyak 2 penderita $(1,23 \%), 1-4$ tahun 1 penderita $(0,62 \%)$, 5-9 tahun sebanyak 55 penderita $(33,74 \%)$ dan 10-14 tahun sebanyak 105 penderita $(64,41 \%)$. Dengan kelainan refraksi myopia 117 orang $(71,78 \%)$, hipermetropia 5 orang $(3,07 \%)$ dan astigmatisma 41 orang $(25,15 \%)$.

Pada literatur keempat oleh Ginting et al, ${ }^{11}$ sebanyak 1684 pasien yang diperiksa dengan pemeriksaan tajam pengelihatan menggunakan Snellen Chart, didapatkan 705 (41,9\%) pasien laki-laki dan $979(58,1 \%)$ pasien perempuan. Digolongkan dengan berbagai golongan usia antara lain, 3-5 tahun sebanyak 90 anak (5,3\%), 6-10 tahun sebanyak 702 anak $(41,7 \%)$ dan 11-15 tahun sebanyak 892 anak (52,9\%). Kelainan refraksi yang didapat dalam penelitian ini berupa miopia simpleks 159 anak $(9,4 \%)$, hipermetropia simpleks 12 anak $(0,7 \%)$, astigmatisma miopia simpleks 182 anak $(10,8 \%)$, astigmatisma hipermetropia simpleks 10 anak $(0,6 \%)$, astigmatisma miopia kompositus 964 anak $(57,2 \%)$, astigmatisma hipermetropia kompositus 174 anak (10,3\%) dan astigmatisma mikstus 183 anak $(10,9 \%)$.

Pada literatur kelima oleh Hidayah et al, ${ }^{12}$ sebanyak 77 anak dilakukan wawancara serta pemeriksaan dengan Snellen chart. Didapatkan 17 anak (24,3\%) mengalamai penurunan ketajam penglihatan dan 53 anak $(75,7 \%)$ penglihatan normal. Terdapat juga 12 anak $(9,24 \%)$ memakai kacamata dan 22 anak $(31,4 \%)$ memiliki kebiasaan yang tidak baik sehingga dapat mempengaruhi ketajaman pengelihatan.

Pada literatur keenam oleh Launardo et al, ${ }^{13}$ didapatkan 185 anak diteliti dengan pembagian informed consent dan dilakukan pemeriksaan visus dengan menggunakan
Kay Picture Crowded LogMAR Book Test didapatkan sebanyak 90 anak laki-laki $(48,6 \%)$ dan 95 anak perempuan $(51,4 \%)$. Terdapat golongan usia 4-<4 tahun sebanyak 59 anak $(31,9 \%), 4-<5$ tahun sebanyak 67 anak $(36,2 \%)$, dan 5-6 tahun sebanyak 59 anak $(31,9 \%)$. Untuk frekuensi kelainan refraksi pada anak usia 3-<4 tahun sebesar $1,7 \%$, usia $4-<5$ tahun sebesar $3,0 \%$ dan usia 5-<6 tahun sebesar $3,4 \%$. Untuk pemeriksaan visus didapatkan sebanyak 180 anak $(97,3 \%)$ normal dan 5 anak $(2,7 \%)$ tidak normal.

Pada literatur ketujuh oleh Mokoginta et $\mathrm{al}^{14}$, terdapat 103 siswa diteliti dengan pemeriksaan mata lengkap menggunakan Snellen Chart, LEA Chart, autorefractor dan Streak Skiascopy, sebanyak 53 siswa $(51,46 \%)$ mengalami kelainan refraksi. Dengan kategori usia mulai dari 7 tahun sebanyak 6 siswa, 8 tahun sebanyak 8 siswa, 9 tahun sebanyak 10 siswa, 10 tahun sebanyak 6 siswa, 11 tahun sebanyak 16 siswa dan 12 tahun sebanyak 8 siswa. Kelainan refraksi berupa miopia ringan 46 orang $(87 \%)$, miopia sedang 5 orang $(9 \%)$ dan miopia berat 2 orang (4\%).

Pada literatur kedelapan oleh Fauzi et al, ${ }^{15}$ sebanyak 2.622 responden dilakukan pemeriksaan mata dengan gold standard menggunakan Optotipe Snellen dan lensa coba, 61 responden mengalami kelainan refraksi. Didapatkan anak laki-laki sebanyak 23 responden $(37,7 \%)$ dan perempuan 38 responden $(62,3 \%)$. Digolongkan berdasarkan lima kelas yaitu, kelas dua 11 orang $(18,03 \%)$, kelas tiga 8 orang $(13,11 \%)$, kelas empat 10 orang $(16,39 \%)$, kelas lima 13 orang $(21,31 \%)$ dan kelas enam 19 orang $(31,15 \%)$.

Pada literatur kesembilan oleh Li et al, ${ }^{16}$ didapatkan sebanyak 7.507 anak, 7.166 anak melakukan pengujian ketajaman visual dengan menggunakan logarithmic tumbling E Chart Standard dan didapatkan 1.407 anak $(19,6 \%)$ mengalami penurunan kelainan refraksi. Anak laki-laki sebanyak 747 orang dan perempuan sebanyak 660 orang. Digolongkan berdasarkan usia, umur 4 tahun sebanyak 3137 anak, 5 tahun sebanyak 3.270 anak dan 6 tahun sebanyak 759 
anak. Dengan kelainan refraksi berupa miopia 423 anak $(5,9 \%)$, hipermetropia 74 anak $(1,0 \%)$ dan astigmatisma 910 anak $(12,7 \%)$.

Pada literatur kesepuluh oleh Hazarika et $\mathrm{al},{ }^{17}$ terdapat 2.000 anak melakukan pemeriksaan komperhensif dengan menggunakan Snellen Chart/E-Chart, slit lamp, funduskopi dilatasi dan lainnya, dan didapatkan laki-laki sebanyak 900 anak dan perempuan sebanyak 1100 anak. Digolongkan berdasarkan usia, 10-12 tahun sebanyak 960 anak (48\%), 13-15 tahun sebanyak 800 anak (40\%) dan 7-9 tahun sebanyak 240 anak (12\%). Dengan kelainan refraksi yang didapat yaitu miopia 680 anak (34\%), hipermetropia 220 anak (11\%) dan astigmatisma 1.100 anak (55\%).

Tabel 1. Hasil kajian literatur yang dipakai dalam penelitian ini

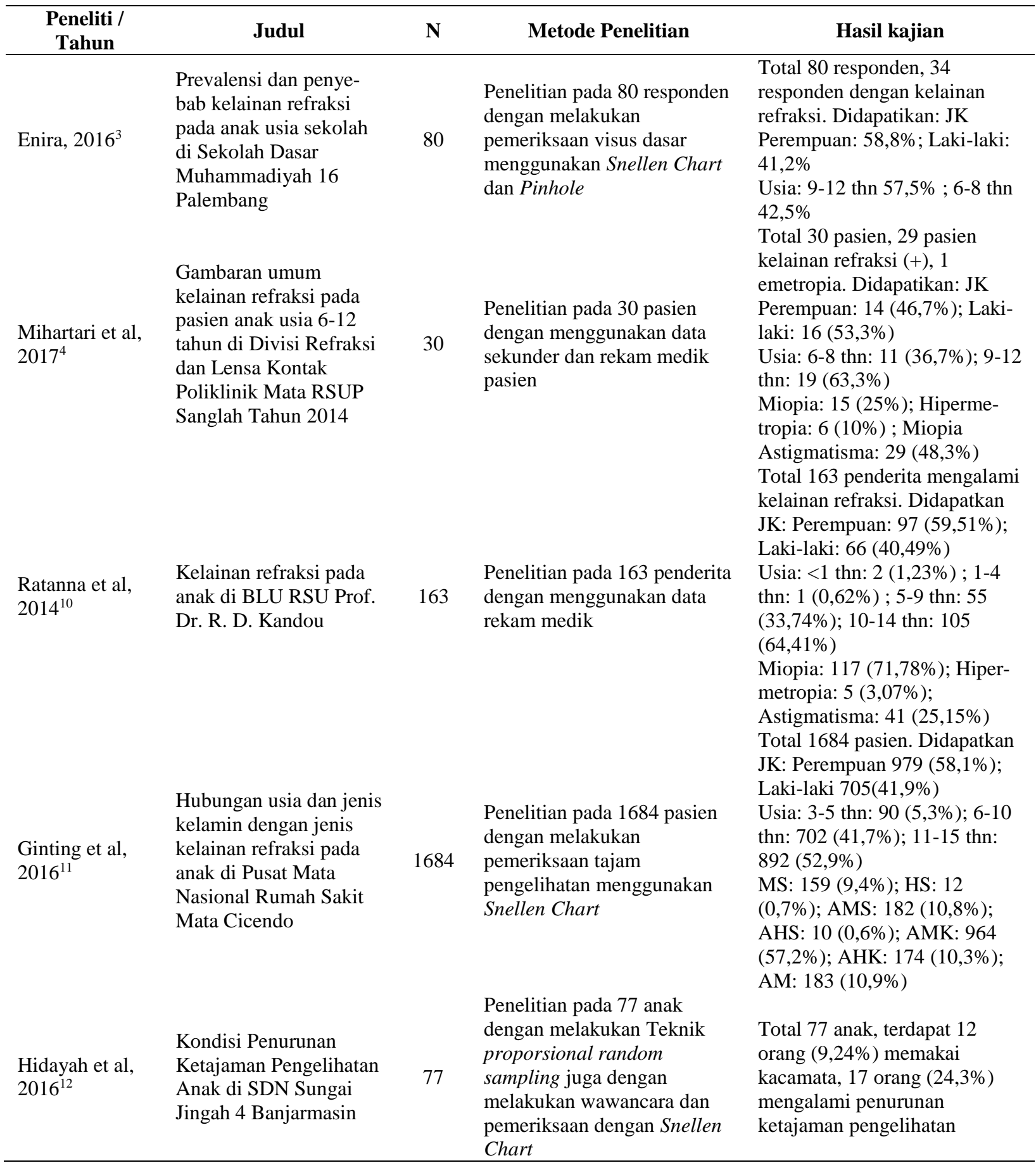




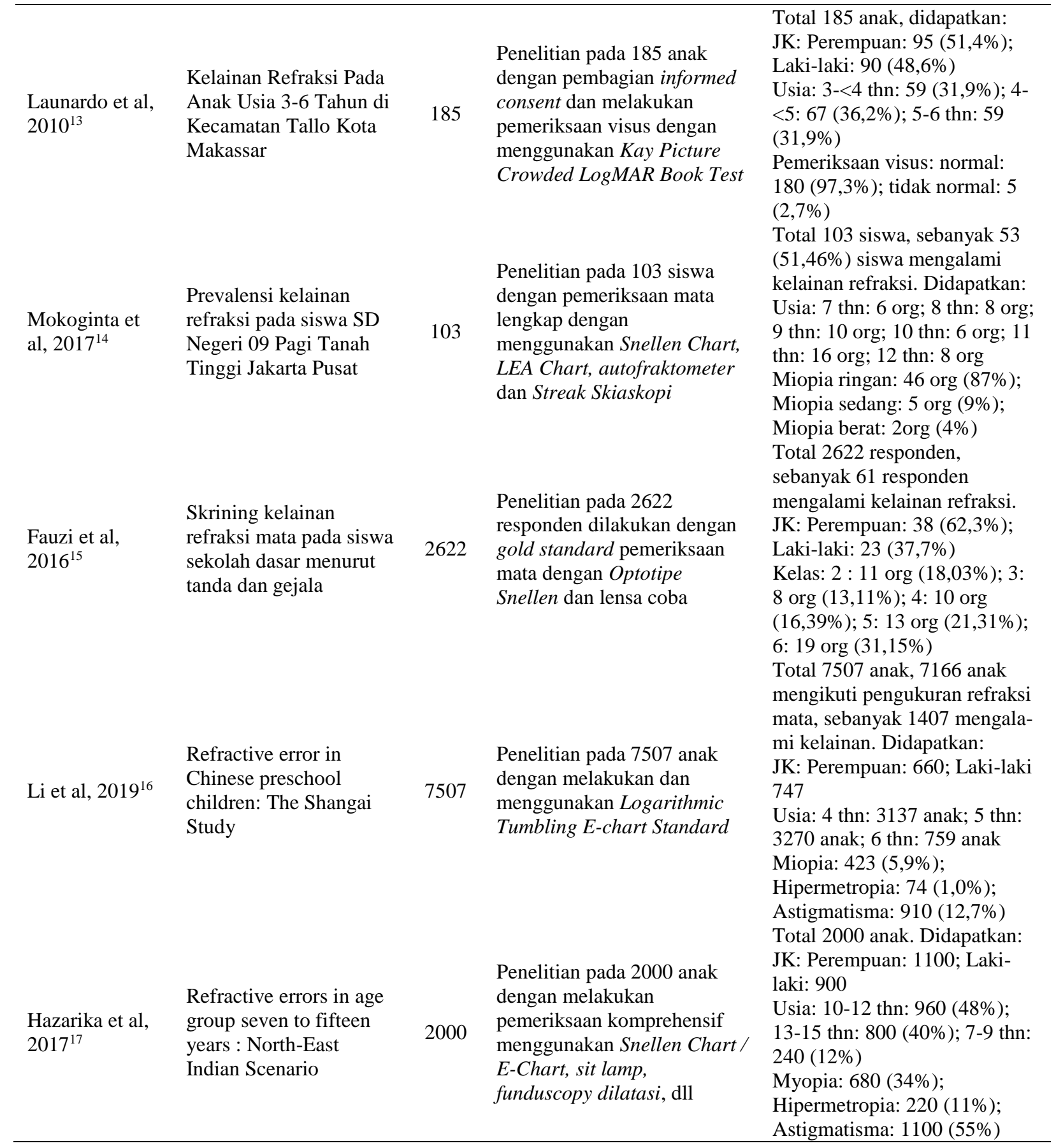

JK Jenis Kelamin; thn tahun; org orang; MS Miopia Simpleks; HS Hipermetropia Simpleks; AMS Astigmatisma Miopia Simpleks; AHS Astigmatisma Hipermetropia Simpleks; AMK Astigmatisma Miopia Kompositus; AHK Astigmatisma Hipermetropia Kompositus; AM Astigmatisma Mikstus

\section{BAHASAN}

Kelainan refraksi atau ametropia adalah keadaan dimana bayangan tegas tidak terbentuk pada retina, sehingga terjadi ketidakseimbangan penglihatan dan menghasilkan bayangan yang kabur. Kelainan refraksi pada anak dapat dilihat tergantung dari usia serta aktivitas yang dilakukannya. Pada anak, gangguan refraksi lebih sering terjadi pada masa-masa pertumbuhan dimana aktivitas semakin meningkat bertepatan dengan aktivitas kerja mata yang terus bertambah melalui aktivitas penglihatan jarak dekat yang umumnya dilakukan oleh anak-anak jaman sekarang.

Angka kemunduran ketajaman penglihatan yang tinggi menunjukkan bahwa perhatian masyarakat terhadap status keta- 
jaman penglihatan pada anak masih kurang. Hal lain yang mengakibatkan tingginya prevalensi kemunduran penglihatan ialah kurangnya inisiatif seorang anak untuk mengeluhkan masalah penglihatan yang dialaminya kepada orang di sekitarnya. Berdasarkan hal tersebut, perhatian orang sekitar sangat berperan penting terhadap kesehatan mata anak; oleh karena itu perhatian perlu lebih ditingkatkan agar penurunan ketajaman pengelihatan pada anak dapat dideteksi secara dini.

Hampir seluruh penelitian melaporkan bahwa anak usia sekolah dasar mengalami gangguan refraksi. Penurunanan tingkat ketajam refraksi biasanya tidak disadari oleh siswa karena pemahaman siswa terhadap kondisi yang terjadi masih belum maksimal. Bahkan, orang-orang di sekitarnya dan di sekolah pun tidak menyadari dan memahami kondisi yang terjadi pada siswa tersebut. Penurunan refraksi ringan jika dibiarkan akan berakibat pada kerusakan mata yang akan semakin parah.

Kelainan refraksi juga dapat ditemukan pada berbagai golongan usia anak. Studi internasional menunjukkan bahwa 25\% anak usia sekolah memiliki suatu bentuk defisiensi penglihatan. Menurut teori, kelainan refraksi pada usia anak lebih banyak terjadi pada usia 9-12 tahun hingga dewasa muda. Yang sangat memrihatinkan ialah $80 \%$ informasi anak selama 12 tahun pertama didapatkan melalui pengelihatan.

Jika dilihat berdasarkan jenis kelamin responden, anak perempuan dan anak lakilaki, seharusnya tidak mengalami kelainan refraksi mata yang berbeda jauh. Kelainan refraksi pada anak perempuan biasanya lebih besar daripada anak laki-laki, dengan perbandingan 1,4:1. Hal ini disebabkan karena anak perempuan dikaitkan dengan aktivitas melihat dekat sangat tinggi dibandingkan anak laki-laki yang kegiatannya banyak di luar rumah.

Pada miopia (rabun jauh), anak yang mengalami gangguan refraksi cenderung melihat dengan posisi mata yang lebih dekat ke obyek, dan mungkin tidak tertarik pada aktivitas yang berjarak jauh. Gejala utamanya ialah sulit melihat jarak objek yang jauh, dan anak biasanya terbantu dengan menyipitkan kedua mata untuk dapat melihat dengan jelas pada objek jauh. Miopia dapat diketahui dengan pemeriksaan mata standar, yakni menggunakan Snellen Chart, autorefractometer, dan pemeriksaan visus menggunakan lensa mata.

Hipermetropia (rabun dekat) dengan gejala utama anak sulit melihat objek yang dekat sehingga anak harus menjauhkan objek tersebut agar jelas terlihat. Sekitar $80 \%$ anak berusia 2-6 tahun mengalami hipermetropia, dan pada usia $>20$ tahun hipermetropia akan menetap statis. Pemeriksaan yang dilakukan sama halnya dengan pemeriksaan mata pada miopia.

Astigmatisma (mata silindris) merupakan kondisi dimana bervariasinya daya refraksi kornea atau lensa karena kelainan bentuk permukaannya sehingga sinar jatuh pada dua titik di depan retina. Keadaan ini menyebabkan penderita harus menjulingkan mata sehingga efek lubang jarum dapat terlihat.

\section{SIMPULAN}

Kelainan refraksi mata pada anak berupa miopia, hipermetropia, dan astigmatisma dapat mengenai anak laki-laki maupun perempuan, dan dapat dikategorikan dengan beberapa golongan usia. Kelainan refraksi anak dapat dipengaruhi oleh berbagai macam aktivitas.

\section{Konflik Kepentingan}

Penulis menyatakan tidak terdapat konflik kepentingan dalam studi ini.

\section{DAFTAR PUSTAKA}

1. Irsch K, Guyton DL. Anatomy of eyes. In: Encyclopedia of Biometrics. Boston: Springer, 2009; p. 11-5.

2. Lestari KD, Handayani TA, Pemayun CID. Karakteristik dan perbedaan kelainan refraksi pada anak usia sekolah dasar di Sekolah Dasar Cipta Dharma Denpasar Februari 2014. Medina. 2019;50:220-5.

3. Enira TA. Prevalensi dan penyebab kelainan refraksi pada anak usia sekolah di Sekolah Dasar Muhammadiyah 16 Palembang [Skripsi]. Palembang: Universitas Muhammadiyah Palembang; 2016. 
4. Mihartari PG, Sutyawan IWE, Triningrat AAMP. Gambaran umum kelainan refraksi pada pasien anak usia 6-12 tahun di Divisi Refraksi dan Lensa Kontak Poliklinik Mata RSUP Sanglah tahun 2014. E-Jurnal Medika Udayana. 2017;6(12):170-4.

5. Wadaani FA, Amin TT, Ali A, Khan AR. Prevalence and pattern of refractive errors among primary school children in Al Hassa, Saudi Arabia. Glob J Health Sci. 2013;5(1):125-35.

6. Nguyen A, Guo X, Inns A, editors. Refractive error prevalence among inner-city students receiving school-based vision screenings and eye exams. JAAPOS. 2019;23(4):191-248.

7. World Health Organization. Global Data on Visual Impairements 2010. Geneva: WHO Press, 2010; p. 1-17.

8. Paramitasari D, Ratnaningsih R. Gambaran kelainan refraksi tidak terkoreksi pada program penapisan oleh Unit Oftalmologi Komunitas Pusat Mata Nasional Rumah Sakit Mata Cicendo di Wilayah Kabupaten Bandung tahun 2017. Jakarta: Ditjen Yankes, 2018.

9. Quigley C, Zgaga L, Vartsakis G. Refracrive error and vision problems in children: association with increased sedentary behavior and reduced exercise in 9-yearold children in Ireland. JAAPOS. 2019;23(3):159.

10. Ratanna RS, Rares LM, Saerang JSM. Kelainan refraksi pada anak di BLU RSU Prof. Dr. R. D. Kandou. e-CliniC. 2014;2(2).

11. Ginting DV, Amiruddin PO. Hubungan usia dan jenis kelamin dengan jenis kelainan refraksi pada anak di Pusat Mata Nasional Rumah Sakit Mata Cicendo. Bandung: Departemen Ilmu Kesehatan Mata Fakultas Kedokteran Universitas Padjadjaran Pusat Mata Nasional Rumah Sakit Mata Cicendo, 2016

12. Hidayah N, Daulay R, Permana LI. Kondisi penurunan ketajaman pengelihatan anak di SDN Sungai Jingah 4 Banjarmasin. Dinamika Kesehatan. 2016;7(2):185-92.

13. Launardo AV, Afifudin A, Syamsu N, dkk. Kelainan refraksi pada anak usia 3-6 tahun di Kecamatan Tallo Kota Makassar. Academia Edu. 2010. Available from: http://pasca.unhas.ac.id/jurnal/ files/af8b92fcf01bd15f027a70f7122e 1ea4.pdf

14. Mokoginta SN, Marsiati H, Indriawati A, Susmiarsih TP. Prevalensi kelainan refraksi pada siswa SD Negeri 09 Pagi Tanah Tinggi Jakarta Pusat. Majalah Sainstekes. 2017;4(1):030-5.

15. Fauzi L, Anggorowati L, Heriana C. Skrining kelainan refraksi mata pada siswa sekolah dasar menurut tanda dan gejala. Journal of Health Education. 2016;1(1)

16. Li T, Zhou X, Chen X, Qi H, Gao Q. Refracive error in chinese preschool children: The Shanghai Study. Eye and Contact Lens: Science \& Clinical Practice. 2019;45(3): 182-7.

17. Hazarika HN, Bhuyan D, Hazarika SC, Addya $S$. Refractive errors in age group seven to fifteen years: North-East Indian Scenario. International Journal of Community Medicine and Public Health. 2017; 4(6): p. 1928-31

18. Strauss L, Azar DT. Physiology optics for refractive surgery: an overview. In: Refractive Surgery (3rd ed). Elsevier Inc, 2020; p. 38-48.

19. Fathimah S, Suryatiningsih, Sari SK. Aplikasi diagnosis kelainan refraksi mata dan tips perawatan mata dengan metode forward chaining berbasis web. Jurnal Infotel. 2015;7:153-63.

20. Budiono S, Saleh TT, Moestidjab, editors. Refraksi. In: Buku Ajar Ilmu Kesehatan Mata. Surabaya: Airlangga University Press, 2013.

21. Meier P, Wiedemann P. Surgery for Pediatric Vitreoretinal Disorders. In: Schachat A, editor. Ryan's Retina (6th ed). Elsevier Inc, 2018; p. 2170-93. 